\title{
How can the Financial Sector Better Serve People and the Planet? The Need to Reimagine Finance
}

\author{
Sara J. Wolcott
}

\begin{abstract}
This article analyses two events in 2010, which attempted to reimagine the role of the financial sector in promoting international development. Several strategies for reimagining are identified and described, and mutually reinforcing barriers to reimagining are outlined. The challenges for moving from ideas to action are particularly difficult for a sector that is often impenetrable to those outside of it. The global nature of the sector is also key to the challenge of reimagining, whether proponents for change are inside or outside of it.
\end{abstract}

\section{Introduction}

Against the backdrop of climate change, the financial crisis of 2008 prompted many to move beyond the important question of 'How can we prevent the banks from failing again?' to the more fundamental question of 'How can the financial sector better serve people and the planet?"' While the crisis did open up the space to question the purpose of finance (Berbier 2009; Chappelle 2009; OECD 2009; Tienhaara 2010), mainstream analyses of financial reform (Reinhart and Rogoff 2009; Turner et al. 2010) has paid little attention to the role of international finance in shaping climate change or how environmental costs and benefits can be factored into reforms. This article highlights the efforts of actors - from within and outside the financial system - who are struggling to make the 'private' financial sector more environmentally sustainable and accountable to the final guarantors of the system - the taxpayer. This article focuses on civil society groups, as they tend to be most excluded from the debates on financial sector governance and yet are deeply affected by the outcomes of those debates (Lawrence 2008). The article explores the attempts to reimagine finance in these groups and the barriers to doing so. It concludes with reflections on the general task of reimagining in development.

\subsection{Methodology}

Building on prior research into the changing social contract between civil society and the finance sector in the context of climate change and the financial crisis (Wolcott 2009), this research included participatory observation in two reimagining spaces: WWF-UK's Finance Lab in London, and the 'Climate Camp' 2010 at the Royal Bank of Scotland (RBS) in Edinburgh. Semi-structured interviews were conducted with a sample of 18 individuals working in this area in the USA and the UK, including three financiers; six non-governmental organisations (NGOs) in the UK; two US-based NGOs who actively engage with private finance and climate change; one of the few US-based funders who funds research and action by civil society into finance and four academic-practitioners who are actively engaged in this space. This was augmented by desk-based research. The analysis highlights the diversity of views within the financial sector and within civil society, even as it suggests that certain cultural tendencies (especially epistemological) characterise each.

\section{Civil society's interest and engagement in finance expands}

All of the informants agreed that the financial crisis led to a flurry of new interest in how finance works and the sector's role in society. In this new context, civil society has had far greater legitimacy to pursue accountability of a formerly 'private' realm (Newell 2008; Newell and Gaffney 2009). A small group of Western NGOs have been at the forefront of this interest, 
Table 1 Explorations of reimagining finance for people and planet

\begin{tabular}{|c|c|c|}
\hline Entry point & Examples & Approach \\
\hline Change from within & $\begin{array}{l}\text { Long Finance (Mainelli and Giffords 2010; } \\
\text { Steven 2010); The London Accord; } \\
\text { Network for Sustainable Financial } \\
\text { Markets; Forum for the Future } \\
\text { (Chappelle 2009); Socially Responsible } \\
\text { Investing }\end{array}$ & $\begin{array}{l}\text { Working within the financial system; usually } \\
\text { done by people with high levels of technical } \\
\text { knowledge of finance; some generating of } \\
\text { expert knowledge by civil society actors } \\
\text { (FOE 2O11) }\end{array}$ \\
\hline $\begin{array}{l}\text { Change from without } \\
\text { - Collaboration }\end{array}$ & $\begin{array}{l}\text { Global Financial Initiative; Reinventing } \\
\text { Bretton Woods Committee; WUF } \\
\text { Finance Lab* }\end{array}$ & $\begin{array}{l}\text { Creates platforms and spaces for financiers and } \\
\text { civil society and the public sector to work } \\
\text { together; generates shared research; participates } \\
\text { with 'experts' in influencing public policy or law; } \\
\text { campaigns with 'insiders' (Umlas 2008) }\end{array}$ \\
\hline $\begin{array}{l}\text { Change from without } \\
\text { - Confrontation }\end{array}$ & $\begin{array}{l}\text { 'Stop Gambling on Hunger' Campaign; } \\
\text { 'Put People First' campaign;* 'Climate } \\
\text { Camp' protests against RBS;* legal case } \\
\text { against HM Treasury* }\end{array}$ & $\begin{array}{l}\text { Strategies vary from 'legal activism' to direct } \\
\text { action on banks to political protests against the } \\
\text { public sector's response to the financial crisis }\end{array}$ \\
\hline $\begin{array}{l}\text { Change from without } \\
\text { - Creating new models }\end{array}$ & $\begin{array}{l}\text { 'Slow Money' campaign (Tasch 2009); } \\
\text { Creating technology for and practices of } \\
\text { complementary currencies } \\
\text { (communityforge.net); publishing ideas for } \\
\text { 'new models' (NEF 2009; Lietaer et al. } \\
\text { 2009) }\end{array}$ & $\begin{array}{l}\text { Thinks a new, diverse, people-centred financial } \\
\text { or monetary system will only occur by people } \\
\text { building it themselves }\end{array}$ \\
\hline
\end{tabular}

increasingly attempting to nudge private finance towards environmental sustainability (Smithey 2010 , pers comm). Their work is built on campaigns that have challenged publicly funded international finance institutions. For example, after successful involvement with the Jubilee Debt Campaign, ${ }^{2}$ and shortly before the financial crisis, research from the Maryknoll Institute in the USA concluded that the 'power' holding back social and environmental justice was held in the private finance sector (Kane 2010, pers comm).

\section{Strategies for reimagining finance}

Strategies for reimagining originate from within and outside the sector. From outside the sector, global civil society has built on the collaborative and confrontational approaches it developed in its engagements with multilateral development banks and transnational corporations (Utting 2008). Confrontational methods vary (Utting 2008; Newell 2004). Recently in the USA, these have included public protests such as the 'Put People First Campaign', direct action platforms such as the 'Climate Camp' ('action' included camping at RBS Headquarters in Edinburgh) (BBC 2010) and the launching of legal cases against the government (e.g. 'PLATFORM vs HM Treasury 2009' on the issue of UK public funds being used to invest in coal and gas plants via RBS, despite the UK government's own legal obligations to reduce such investments).

From within the sector, many financiers are also looking for ways to align the financial system with the planet's resources. Some explicitly see their work as part of a larger change strategy. Socially responsible investing (SRI), which is one of the few investment sectors that showed steady growth between 2007 and 2010 (SIFF 2010), sees itself as 'taking place within broader movements for change' (Umlas 2008: 1020).

Table 1 offers a sample of various entry points for engaging with the financial sector working from within the financial system and those who are primarily situated outside of it, using a mixture of collaborative, confrontational (Utting 2008) and 'new model' alternatives.

Informants found advantages and disadvantages to each approach, depending upon their positionality and their views on which rules need to change. As 
Newell (2004) asked, 'Whose rules rule?’ For example, some of the participants interacted with at the 'Climate Camp' from within the financial sector felt that the WWF Finance Lab would not do 'anything useful' to change finance; others participating in the Finance Lab understandably felt that it was 'exactly what was needed' to bring together the myriad of different groups working to change finance.

\section{Mutually re-enforcing barriers}

Regardless of their preferred strategy, all of the informants expressed frustration - but not necessarily surprise - that in this unprecedented moment, the public (especially in the UK, with its commitment to international development) has not demanded a greater re-assessment of the purpose of 'private' finance. Dearden, from Jubilee South, expressed this disappointment:

\section{Not only did civil society fail to stop the bankers receiving blank cheques, but now the public is frustrated and disempowered even as they are losing social services. They do not have a sense of ownership or control of these banks, even though it is their money that was used to bail them out. They complain about bonuses but do not get to the heart of the issues. I am really worried about the British public's lack of response. (Dearden 2010, pers comm)}

The informants suggest that the public's lack of response and the subsequent challenges of reimagining has several causes, which mutually reinforce one another.

\subsection{Different levels of understanding and awareness of the financial sector}

All of the informants agreed that the dearth of public awareness and understanding of how finance works and why it matters, plays a critical role in the perpetuation of the status quo.

Differences of opinion on how to build this understanding (e.g. engaged participation vs more passive learning) emerged within civil society and financiers who are deeply engaged with this space, and not always in the ways one would predict.

\subsection{Differing visions and use of ideas}

Visions range from creating a financial system with 'green and socially just investments', to a financial system that stops fueling carbon-based growth (or even growth per se). Many aim for a 'both and' approach, for example PLATFORM London commissioned a report by a former
PriceWaterhouseCoopers consultant on the benefits of a Green Investment Bank while sending some of its staff to 'Climate Camp', where participants argued that a Green Investment Bank would not tackle the fundamental problem of being 'hooked' on economic growth.

Another challenge to collective reimagining is using the same 'new idea' differently. For example, many actors are incorporating 'new' ideas from ecosystems such as complexity and resilience. 'Financiers are slowly learning from science about systems management and chaos theory. Financiers are rediscovering that you can't control the outcomes of the system' (Kidney 2010, pers comm). The Governor of the Bank of England encouraged economists to learn from ecology and epidemiology on how to cope with instability (although he cautions against 'going too far with this approach', King 2010). Mainelli and Giffords (2010) argues that deconcentration and diversity are needed in the sector because 'too big to fail is too big to regulate' (a common refrain - see Mizner 2009). Currency expert Bernard Lietaer relies upon the importance of 'resilience' in arguing for complementary currencies ${ }^{3}$ as a key part of the solution to the 'systemic crisis' (Lietaer $e t$ al. 2009). But each one of these uses of resilience and diversity is different with different implications for action (e.g. deconcentration or diversification?) - they do not easily add up to a new vision.

\subsection{Differing political power bases}

In a sector that has such heavy political influence (Boone and Johnson 2010), there is much talk of the need for 'alternatives' to come together for a shared vision. Based on his experience of pulling together the Ford Foundation-funded Global Finance Initiative (GFI), Waddell reflected on the challenge of building such a shared vision:

There is no real vision of what the financial sector (for sustainability) should be like. The best theorists certainly don't have it... You can develop the political will by developing a vision. They will understand it and will fight for it. The best thinkers say these crises are just inevitable - which showes you the limitations of their imagination. The only way to get out of this is by thinking about it differently. But then personalities and politics get in the way. It takes time - and money.

(Waddell 2010, pers comm) 
Funding for new thinking on finance for those outside of the financial sector ${ }^{4}$ dramatically reduced after the crisis, as funders became reluctant to fund 'new thinking' despite the 'clear need for it' (Smithey 2009, pers comm). But do these networks count? Former financier Mainelli explained it this way: 'as a financier working with the flows of billions of dollars around the world, why should I listen to the NGOs'? (Mainelli 2010, pers comm). All of my informants, including the financiers, felt that the financial crisis, which may have briefly brought the financial world to its knees, did not alter this fundamental and familiar (Newell 2004) challenge.

\subsection{Different 'epistemologies' between financiers and 'everyone else'}

Ways of knowing often reinforce barriers to engagement between experts and citizens (Leach et al. 2005). This is no different in finance (de Goede 2005). One of the key disconnects is around beliefs related to 'rationality'. Financiers generally see themselves and their decisionmaking as 'rational' (Tantram 2010, pers comm; Mainelli 2010, pers comm; Odgers 2010, pers comm). The fallacy of this position was demonstrated by the crisis (Taleb 2007; Thaler and Sunstein 2009). To an outsider, the herd mentality of financiers and complexity of the systems they put their faith in may not appear particularly 'rational'. Nevertheless, 'rationality' is a core part of the finance sector's identity and contributes to a mindset that 'is very hard to get out of' (Kidney 2010, pers comm). Mainelli contrasted the 'rational', spreadsheet, fact-based, financial sector with the 'non-rational', 'flip chart' culture of the NGOs. This reflects a type of 'instrumental rationality', or the 'systematizing, objectifying and technicalizing mentality that dominates industry... unconcerned with ultimate goals or values' (Yankelovich 1991). This was seen by civil society respondents as a key barrier to engagement. Questioning this epistemology was to expose oneself to the risk of seeming uninformed and impractical.

\subsection{The inherently global nature of the finance sector Finally, how can the financial sector be made more accountable to 'society' given its global nature? How can such a sector be held to account without a clear transnational civil society mechanism (Held et al. 2010)? These questions will need to be addressed as the global public}

goods agenda becomes ever more important in an era of climate change and resource scarcity.

\section{Moving forward - slowly}

Different visions, understandings, levels of political power and ways of knowing between (and often within) the finance sector and civil society make reimagining finance challenging. Yet, drawing from the history of social justice movements, many commentators and activists remain cautiously optimistic.

Dave Kane, at Maryknoll Institute (USA), is one such person. He compares the present situation to the early stages of the 'Jubilee Debt' campaign when civil society was just beginning to 'get their heads around debt'. Hopeful that efforts to tackle private finance is the beginning of the next 'big' global movement, he spent 2009-10 educating his network of civil society organisations on private finance. Other organisations are also working to build citizen's awareness and expertise through expanding their adult education and movement-building programmes. ${ }^{5}$ They are hoping to overcome the barrier that they feel instrumental rationality has become between 'citizens' and 'experts' and to build popular support to redefine the purpose of finance.

As with other initiatives to increase citizen 'expertise' around technical, expert issues (Fischer 2007; Fortmann 2008), this is a 'slow race' (Leach and Scoones 2006) where 'whose knowledge counts?' is a critical question. Insiders, outsiders and collaborators know they are in for a long haul - indeed, one of the primary changes all actors seek is 'long-term thinking' in a sector known for its speed and short-termism (Mainelli and Giffords 2010).

\section{Lessons for reimagining?}

It has been argued here that attempts to change finance are central to reimagining development. But changing highly technical epistemological communities, embedded in structures which hold power and which are entangled in a 'growth or bust' perspective is difficult, even when crises present 'unprecedented' opportunities.

The ability to move from 'imagination' to 'action' is particularly challenging for any reimagining endeavour. 'Ideas are a dime a dozen', Waddell said with a sigh. Slater (2010, pers comm) agreed: 
'Once people do question money and start reading the literature, it is not hard to come up with different ways of creating money. But what is the path of transition? What can we really do?' How does one build the bridge between ideas and agency for 'real change' given the political nature of seemingly technical economic institutions such as markets? (Chang 2010).

Providing opportunities and spaces for different thinking is essential. For example, one of the informants experienced 'Climate Camp' as a 'transformational experience'. He had previously felt little ability to engage with private finance outside of attending workshops and occasionally engaging in protests. But his active participation in 'Climate Camp' empowered him to leave his job and start a local renewable energy cooperative.

\section{Notes}

1 Variations of this phrase can be found throughout this space, including: WWF UK's Finance Lab, New Economic Foundation's work on finance and business; the UK-based NGO, People and Planet; ActionAid and Long Finance.

2 Many of the NGOs working on changing private finance, such as Cornerhouse, Bretton Woods project, Eurodad, World Resources Institute, Friends of the Earth and the Center for Environmental Law have a history of activism with regard to the World Bank and other global financial institutions.

3 Complementary currencies are currencies that 'complement' but are independent from

\section{References}

BBC (2010) Climate Protest Camp Targets RBS Headquarters, 19 August, www.bbc.co.uk/ news/uk-scotland-edinburgh-east-fife- 1020007

Berbier (2009) Global Green New Deal, Nairobi: United Nations Environment Programme

Boone, P. and Johnson, S. (2010) 'Will the Politics of Global Moral Hazard Sink us Again?', The Future of Finance: The LSE Report, London: London School of Economics and Political Science

Chang, H.J. (2010) 23 Things They Don't Tell You About Capitalism, London: Allen Lane

Chappelle, A. (2009) Rethinking Capital, London: Forum for the Future, www.forumforthe future.org/projects/rethinking-capital

CNN (2011) IMF Calls for Dollar Alternative, 10 February, http://money.cnn.com/ 2011/02/10/markets/dollar/index.htm
Linking one crisis - finance - with another, more 'understandable' crisis such as food prices (e.g. the World Development Movement's campaigns around commodity speculation) may be another way of moving ideas into action (Chow 2010, pers comm; Powell 2010, pers comm).

The external demand for greater public accountability from a sector with such influence on sustainability will likely persist. Meeting this demand through reimagining, entails the marrying of diverse perspectives and analyses, imaginative thinking and appropriate action over a period of time. This requires planning. Without ongoing efforts, neither civil society organisations nor the financiers seeking change from within will be prepared to seize the next window of opportunity - possibly the next crisis.

national or global currencies. Historically, they have been created by local communities to increase liquidity and stability. Several informants (Bendall, Slater, Waddell) noted that the role of the monetary system in creating sustainable growth (as explained by Lietaer 2001 and Douthwaite 2009) has not been a significant part of the current debates, although discussion of a 'one world' currency is continuing (CNN 2011).

4 The Soros-funded Institute for New Economic Thinking has not focused on environmental sustainability.

5 Including: Third World Network in Ghana, the New Economic Foundation, PLATFORM London, World Development Movement, FOE.

de Goede, M. (2005) Virtue, Fortune and Faith: A Genealogy of Finance, Minneapolis: University of Minnesota

Douthwaite, R. (2009) The Ecology of Money, Schumacher Briefings, London: Green Books

Fischer, I. (2007) Citizens, Experts and the Environment: The Politics of Local Knowledge, North Carolina: Duke University Press

FOE (2011) How to Integrate Sustainability Criteria in Capital Requirements, Friends of the Earth, BankTrak, Campagna per la Riforma della Banca Mondiale, Brussels

Fortmann, L. (2008) Participatory Research in Conservation and Rural Livelihoods: Doing Science Together, London: Earthscan

Held, D.; Kaldar, M. and Quah, D. (2010) 'Hydra Headed Crisis', Global Policy Journal 1.1, www.globalpolicyjournal.com/articles/global- 
governance/hydra-headed-crisis (accessed 5 March 2010)

King, M. (2010) 'Uncertainty in Macroeconomic Policy Making: Art or Science?', lecture for the Royal Society Conference by Mervyn King, 22 March 2010, London, www.bankofengland.co.uk/publications/news/ 2010/034.htm (accessed 13 July 2011)

Lawrence, R. (2008) 'NGO Campaigns and Banks: Constituting Risk and Uncertainty', Research in Economic Anthropology 28: 241-70

Leach, M. and Scoones, I. (2006) The Slow Race, London: Demos

Leach, M.; Scoones, I. and Wynne, B. (2005) Science and Citizens: Globalization and the Challenge of Engagement, London: Zed Press

Lietaer, B. (2001) The Future of Money, London: Greenback Publishers

Lietaer, B.; Ulanowicz, R. and Goerner, S. (2009) Options for Managing a Systemic Bank Crisis, http://sapiens.revues.org/index 747.html (accessed 25 April 2010)

Mainelli, M. and Giffords, B. (2010) The Road to Long Finance: A Systems View of the Credit Scrunch, London: Centre for the Study of Financial Innovation

Mizner, D. (2009) 'Krugman, Stiglitz, Roubini, Taleb, Baker Agree: Nationalize', Daily Kos,

9 February, www.dailykos.com/ story/2009/2/9/14316/26025/353/695269 (accessed 18 June 2010)

NEF (2009) The Great Transition: A Tale of How it Turned out Right, London: New Economics Foundation

Newell, P. (2008) 'Civil Society, Corporate Accountability and the Politics of Climate Change', Global Environmental Politics 8.3: 122-53

Newell, P. (2004) 'Globalisation and the Environmental Movement: Cooperation, Confrontation and Resistance', Noveaux Mondes 14: 45-60, Geneva: Centre de Recherches Enterprises et Sociétés (CRES)

Newell, P. and Gaffney, E. (2009) Globalising Corporate Citizenship: Political and Theoretical Considerations, Working Paper CSGP 09/4, Peterborough: Trent University
OEGD (2009) Declaration on Green Growth, 25 June, www.oecd.org/dataoecd/58/34/ 44077822.pdf (accessed 5 December 2010)

Reinhart, C. and Rogoff, K. (2009) This Time is Different: Eight Centuries of Financial Folly, London: Basic Books

SIFF (Social Investment Forum Foundation) (2010) Report on Socially Responsible Investing Trends in the United States, Social Investment Forum Foundation, www.socialinvest.org/resources/ research/documents/2010TrendsES.pdf (accessed 6 June 2011)

Steven, D. (2010) Time to Stop Betting the House: Mortgages, Resilience and the Long Finance, London: Centre for the Study of Financial Innovation

Taleb, N. (2007) The Black Swan: The Impact of the Highly Improbable, New York: Random House

Tasch, W. (2009) Inquiries into the Nature of Slow Money, Boston: Chelsea Green Publishing

Thaler, R. and Sunstein, Cass (2009) Nudge, London: Penguin Press

Tienhaara, K. (2010) 'A Tale of Two Crises: What the Global Financial Crisis Means for the Global Environmental Crisis', Environmental Policy and Governance 20.3: 197-208

Turner, A.; Haldane, A.; Woolley, P.; Wadhwani, S.; Goodhart, C.; Smithers, A.; Large, A.; Kay, J.; Wolf, M.; Boone, P.; Johnson, S. and Layard, R. (2010) The Future of Finance: The LSE Report, London: London School of Economics

Umlas, E. (2008) 'The Global Expansion of SRI: Facing Challenges, Meeting Potential', Development and Change 39.6: 1019-36

Utting, P. (2008) 'The Struggle for Corporate Accountability', Development and Change 39.6: 959-75

Wolcott, S. (2009) 'The Evolution of the Social Contract in the Context of Climate Change and the Financial Crisis', MA thesis, Brighton: IDS

Yankelovich, D. (1991) Coming to Public Judgement: Making Democracy Work in a Complex World, Syracuse, NY: Syracuse University Press 